\title{
Deteksi Topik Tentang Tokoh Publik Politik Menggunakan Latent Dirichlet Allocation
}

\author{
Faizun Nuril Hikmah ${ }^{\star 1}$, Setio Basuki ${ }^{2}$, Yufis Azhar ${ }^{3}$ \\ 1,2,3 Teknik Informatika/Universitas Muhammadiyah Malang \\ faizunnuril03@gmail.com¹, setiobasuki.umm@gmail.com², yufis@umm.ac.id ${ }^{3}$
}

\begin{abstract}
Abstrak
Twitter merupakan salah satu Social Networking yang memperbolehkan pengguna untuk mengirim dan membaca sebanyak 140 karakter. Berdasarkan survey sekitar 500 juta tweet tiap harinya yang dikirim melalui twitter. Data-data tersebut dapat berupa opini-opini publik mengenai politik, tokoh publik, makanan, dan lain sebagainya. Data tersebut akan diolah dengan teknik Topic Detection untuk menghasilkan suatu topik yang sedang marak dibicarakan masyarakat tentang tokoh publik politik. Permasalahan dalam penulisan ini yaitu, bagaimana mengekstraksi suatu tweet tentang tokoh publik politik dari pengguna Twitter. Data tweet yang diambil tentang tokoh publik politik diantaranya yaitu mengenai Joko Widodo, Basuki Tjahaja Purnama (Ahok), Anies Baswedan, Sandiaga Uno, dan Habib Rizieq Shihab. Dengan adanya data atau tweet tentang tokoh publik politik dapat diolah menggunakan metode Agglomerative untuk mengcluster tiap data yang akan digunakan sebagai topik acuan, LDA (Latent Dirichlet Allocation) yang akan berfungsi sebagai pemodelan topik dari tweet-tweet yang telah tercluster, serta TF-IDF untuk mengetahui tweet mana saja yang mengandung kata-kata dalam LDA yang akan dijadikan sebagai topik acuan. Sehingga akan menghasilkan deteksi topik yang relevan berdasarkan tweet mengenai tokoh publik politik.
\end{abstract}

Kata Kunci: Deteksi Topic, Tokoh Publik Politik, Agglomerative Hierarchical Clustering, LDA, TFIDF

\section{Abstract}

Twitter is a Social Networking website that allows users to send and read 140 characters. Based on a survey of about 500 million tweets per day sent via twitter. These data can be public opinions about politics, public figures, food, and more. The problem in this paper is, how to extract a tweet about the public political character of Twitter users. Tweet data taken on public political figures include Joko Widodo, Basuki Tjahaja Purnama (Ahok), Anies Baswedan, Sandiaga Uno, and Habib Rizieq Shihab. Given the data or tweets about public political figures it will be processed by using Agglomerative method to cluster each data, LDA (Latent Dirichlet Allocation) which will serve as a topic modeling of twisted tweets, and TF-IDF for know which tweets contain the words in the LDA that will serve as a reference topic. This will result in the detection of relevant topics based on tweets about public political figures.

Keywords: Topic Detection, Public Political Figure, Agglomerative Hierarchical Clustering, LDA, TF-IDF

\section{Pendahuluan}

Twitter merupakan Social Networking website yang memperbolehkan pengguna untuk mengirim dan membaca 140 karakter, atau sering disebut tweets [1]. Berdasarkan survey yang telah dilakukan terdapat 304 juta pengguna tiap bulannya yang aktif menggunakan twitter. Sekitar 500 juta tweet tiap harinya yang dikirim melalui twitter. Dengan banyaknya tweet yang pengguna posting tiap harinya, terdapat banyak pula data-data yang didapat dari tweet-tweet tersebut. Datadata tersebut dapat berupa opini-opini publik mengenai politik, tokoh publik, makanan, dan lainnya. Pada penelitian ini, data yang diambil tentang opini atau postingan pengguna tentang tokoh publik khusunya tokoh publik yang bergelut dalam dunia politik. Data tersebut akan diolah dengan teknik Topic Detection untuk menghasilkan suatu topik yang sedang marak dibicarakan masyarakat tentang tokoh publik politik.

Untuk melakukan Topic Detection atau Deteksi Topik dapat diimplementasikan menggunakan metode Clustering, dimana pengertian clustering itu sendiri ialah suatu metode 
pengelompokan berdasarkan ukuran kedekatan (kemiripan) suatu data. Pengelompokkan klaster berdasarkan nilai kedekatan suatu sample data yang ada dan pengelompokkan tidak harus mempunyai data yang sama. Secara garis besar ada beberapa kategori dalam clustering, seperti metode hirarki dimana pada metode hirarki terdapat dua jenis algoritma, salah satu algoritmanya yaitu, Agglomerative. Dimana algoritma Agglomerative yang akan diimplementasikan dalam penelitian ini untuk mengetahui cluster-cluster dari data yang telah terkumpul. Topik yang telah ter-cluster akan diolah menggunakan metode LDA (Latent Dirichlet Allocation) untuk menghasilkan pemodelan topik mengenai tokoh publik politik.

Permasalahan dalam penulisan ini yaitu, bagaimana mengekstraksi suatu tweet tentang tokoh publik politik dari pengguna Twitter. Data tweet yang diambil tentang tokoh publik politik diantaranya yaitu mengenai Joko Widodo, Basuki Tjahaja Purnama (Ahok), Anies Baswedan, Sandiaga Uno, dan Habib Rizieq. Dengan adanya data atau tweet tentang tokoh publik politik tersebut akan diolah dengan menggunakan metode Agglomerative untuk mengcluster tiap data dan LDA (Latent Dirichlet Allocation) yang akan berfungsi sebagai pemodelan topik dari tweettweet yang telah tercluster. Hal tersebut akan memudahkan pengguna untuk mengetahui suatu topik apakah yang sedang dibicarakan tentang tokoh publik politik. Namun, deteksi topik disini berbeda dengan Trending Topic pada Twitter. Deteksi topik yang diangkat dalam permasalahan tugas akhir ini yaitu mendeteksi topik tentang tokoh publik politik, dimana data-data yang digunakan untuk deteksi topik bukan mendeteksi topik yang sedang marak diperbincangkan pada hari itu seperti Trending Topic. Sedangkan pada Trending Topic yaitu mendeteksi topik apa yang sedang marak diperbincangkan saat itu juga dan pada hari itu.

Berbeda dengan penelitian-penelitian sebelumnya, peneliti Saud Alashri [2], mendistribusikan beberapa topik mengenai calon presiden AS, seperti topik tentang Iran, ISIS, Imigrasi, dan sebagainya. Dari topik-topik tersebut akan dideteksi trending topik dari komentar publik mengenai calon presiden AS yang menggunakan metode LDA dan juga menganalisa sentimen dari topik calon presiden AS. Serta pada penelitian Suvarna D. Tembhurnikar [3], menggunakan metode BNgram untuk melakukan deteksi topik dari sosial media, Twitter. Dimana pada metode BNgram untuk mengklaster data menggunakan perhitungan " $d f$-idff", berdasarkan nilai $d f$-idft yang telah dihitung untuk setiap $n$-gram maka peringkat $n$-gram akan dibuat dan dibentuk menjadi cluster. Proses clustering diulang sampai kesamaan antar cluster terdekat turun dibawah nilai ambang batas yang telah ditentukan. Semua cluster dibentuk dengan merangking berdasarkan nilai $d f$-idft tertinggi. Dan setiap klaster merupakan satu topik. Pada penelitian Tahta Alfina [4], melakukan analisa perbandingan antara metode Hierarchical Clustering dan K-Means dalam mengklaster data. Dengan didapatkan hasil bahwa algoritma Hierarchical Cluster menghasilkan pengelompokkan yang jauh lebih baik daripada K-Means dalam semua pengujian.

Dari penelitian-penelitian sebelumnya dan juga permasalahan yang ada. Pada tugas akhir ini akan membangun sebuah perangkat lunak Deteksi Topik Tentang Tokoh Publik Politik Menggunakan Twitter API. Dengan demikian, pengguna akan lebih mudah untuk membaca topik apakah yang sedang dibicarakan mengenai tokoh publik politik.

\section{Metode Penelitian}

\subsection{Analisa Masalah}

Dalam media sosial seperti Twitter, masyarakat banyak mengeluarkan opini-opini pendapat mereka tentang publik figur atau bahkan tokoh politik seperti, Joko Widodo, Basuki Tjahaja Purnama (Ahok), Sandiaga Uno, Anies Baswedan dan Habib Rizieq. Dengan adanya opini-opini masyarakat tersebut dapat diolah dengan menggunakan metode Agglomerative Hierarchical Clustering untuk mengelompokkan data tweet mengenai lima tokoh tersebut. Sehingga akan menghasilkan beberapa kelompok yang nantinya dapat diketahui jumlah topik acuannya. Selain itu pada penelitian ini juga menggunakan metode Latent Dirichlet Allocation (LDA) yang digunakan sebagai pengolahan topik model yang akan menghasilkan topik mengenai lima tokoh tersebut. Dikarenakan hasil pemodelan topik LDA berupa kata-kata yang tidak memiliki makna dan user tidak dapat memahami makna topik tersebut, maka menggunakan metode TFIDF untuk mengetahui tweet mana saja yang banyak mengandung kata-kata dalam LDA. Tweet tersebut yang akan dijadikan sebagai topik acuan agar user mengetahui makna dari topik-topik yang telah dihasilkan menggunakan metode $L D A$ dan akan dijadikan sebagai topik akhir dari tugas akhir ini. Sehingga tujuan pada penelitian ini yaitu mengetahui topik apakah yang sedang dibicarakan oleh masyarakat tentang lima tokoh yang menjadi acuan dalam penelitian ini dapat tercapai.

REPOSITOR, Vol. 2, No. 4, April 2020: 415-426 


\subsection{Analisa Desain Sistem}

Adapun gambaran dari sistem yang akan dibangun pada penelitian tugas akhir ini akan dijelaskan pada Gambar 1.

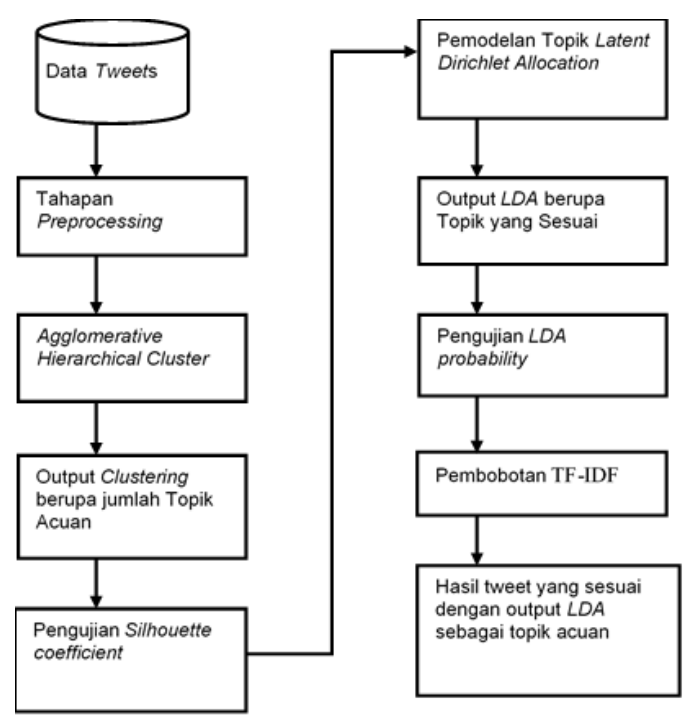

\subsubsection{Tahapan Preprocessing}

Gambar 1. Desain Sistem

Pada tahap ini bertujuan untuk menghilangkan Stopword Removal (kata-kata dasar yang tidak penting, seperti kata "ada","siapa","dari", dan kata-kata dasar lainnya). Selain itu untuk Normalisasi Fitur (menghilangkan komponen dalam tweet seperti @username, RT, \#Hastag, $U R L)$. Serta untuk merubah huruf menjadi huruf kecil. Berikut merupakan contoh data tweet dari kelima tokoh pada tahap preprocessing pada Tabel 1.

Tabel 1. Data Preprocessing

\begin{tabular}{ll}
\hline \multicolumn{1}{c}{ Data Sebelum preprocessing } & \multicolumn{1}{c}{ Data Sesudah preprocessing } \\
\hline RT @singa_com: & $\begin{array}{l}\text { kngkanrizieq knginrizieq arab biadab } \\
\text { penghina pancasila mengkritik }\end{array}$ \\
\#KANDANGKANRIZIEQ & almarhum bung karno penista \\
\#KandanginRizieq ARAB BIADAB & \\
@syihabrizieq PENGHINA & \\
PANCASILA, MENGKRITIK & \\
ALMARHUM BUNG KARNO, PENISTA & \\
\hline RT @DpaOdojCIREBON: 15 Gara- & gara ahok dibikin ribet eksekusi \\
gara Ahok, semua dibikin ribet, & ahokdipenjara secepat \\
eksekusi \#AhokHarusDipenjara & \\
secepatnya & \\
\hline RT @wakilgubernurKW: Presiden & presiden di tuduh pki trus m aja \\
@jokowi Di Tuduh PKI Oleh & jokowittfpi \\
@syihabrizieq Trus @DivHumasPolri & \\
@CCICPolri @BNPTRI Diam Aja? & \\
\#JokowiTakutFPI? & \\
\hline RT @sandiuno: \#MakasihAnies & sihanies trending topic pendidikan \\
trending topic? Berarti kalian semua & merupkunci utama pembann manusia \\
yakin kalau pendidikan merupakan & \\
kunci utama dalam pembangunan & \\
manusia. & \\
\hline RT @gitamontolalu: & \\
https://t.co/4IHGsbrnIK Kok bisa & anggaran rpt jmn anies baswedan \\
anggaran berlebihan Rp.23.3T jmn & \\
Anies Baswedan ogah ah pilihdia aku & \\
Basuki Djarot No.2 & \\
\hline
\end{tabular}




\subsubsection{Tahapan Agglomerative Hierarchical Clustering}

Tahapan kedua yang dilakukan setelah preprocessing yaitu tahapan clustering. metode Agglomerative Hierarchical Clustering sendiri ialah metode yang menggunakan strategi desain Bottom-Up yang dimulai dengan meletakkan setiap obyek sebagai sebuah cluster tersendiri dan selanjutnya menggabungkan objek-objek cluster. Objek-objek cluster tersebut menjadi cluster yang lebih besar dan lebih besar lagi sampai akhirnya semua obyek menyatu dalam sebuah cluster atau proses dapat pula berhenti jika telah mencapai batasan kondisi tertentu [5]. Hasil keseluruhan dari algoritma Hierarchical Clustering dapat digambarkan dalam sebuah grafik, yang disebut dengan dendrogram. Dimana dendrogram akan menggambarkan dari penggabungan klaster-klaster yang ada serta memperjelas proses hirarki tersebut [6].

Pada tahapan clustering pada penelitian ini menggunakan library weka untuk menentukan kelompok-kelompok data dan mengetahui jumlah topik acuan. Berikut parameter yang digunakan dalam tahapan clustering diantaranya:

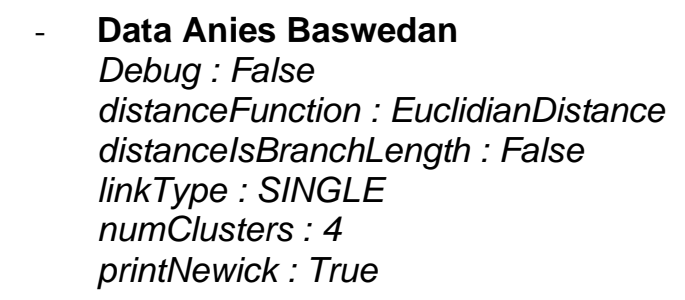

- Data Basuki Tjahaja Purnama

Debug : False

distanceFunction : EuclidianDistance

distancelsBranchLength : False

linkType : SINGLE

numClusters : 4

printNewick : True

- Data Joko Widodo

Debug : False

distanceFunction : EuclidianDistance

distancelsBranchLength : False

linkType : SINGLE

numClusters : 3

printNewick : True

- Data Habib Rizieq Shihab

Debug : False

distanceFunction : EuclidianDistance

distancelsBranchLength : False

linkType : SINGLE

numClusters : 4

printNewick : True

- Data Sandiaga Uno

Debug : False

distanceFunction : EuclidianDistance

distancelsBranchLength : False

linkType : SINGLE

numClusters : 3

printNewick : True Gambar 3.

Berikut hasil yang didapatkan dari tahapan clustering dapat dilihat pada Gambar 2 dan 

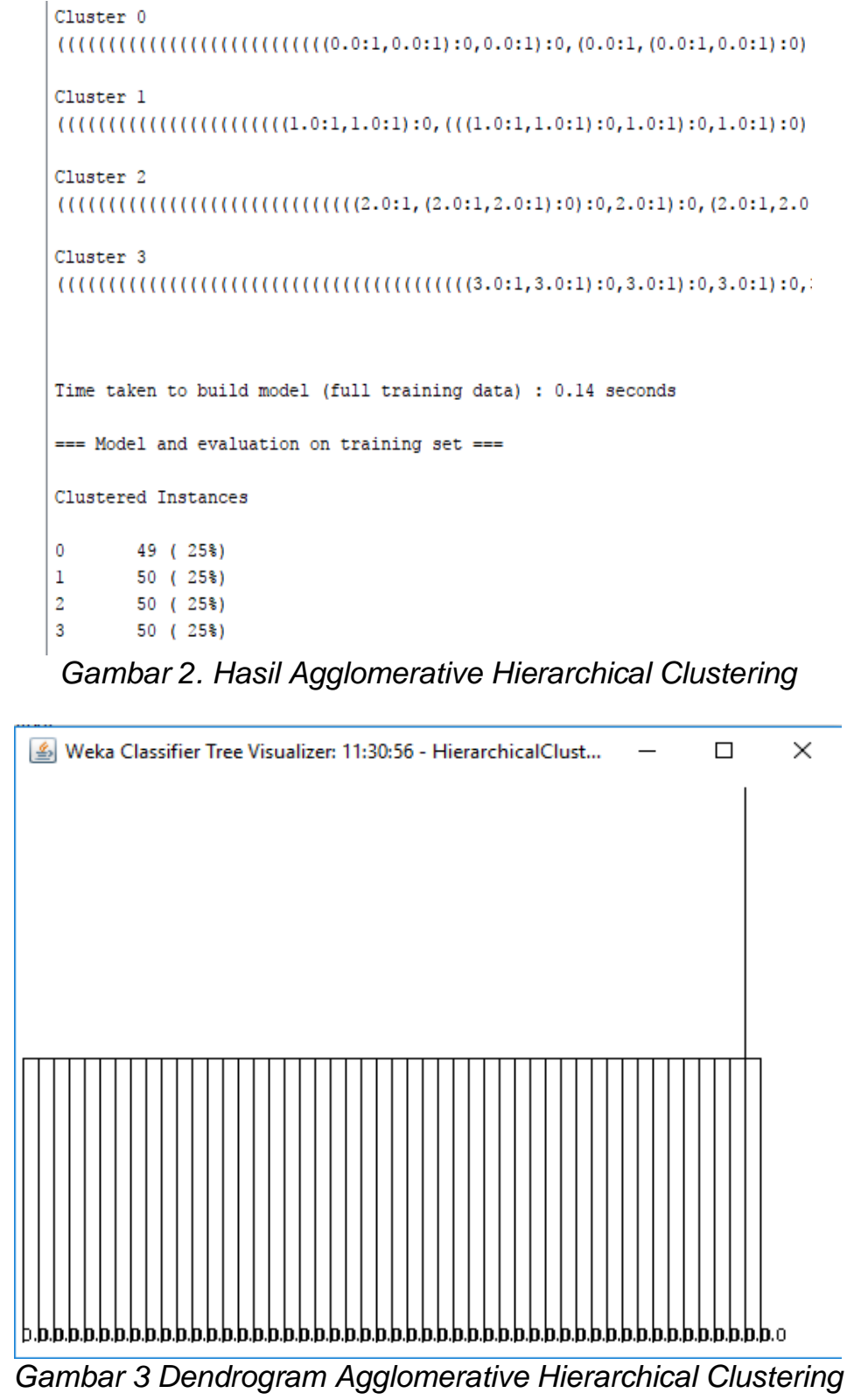

\subsubsection{Tahapan Pemodelan Topik LDA}

Tahapan ketiga yang dilakukan setelah clustering yaitu tahapan pemodelan topik yang menggunakan metode Latent Dirichlet Allocation (LDA). Pengertian Latent Dirichlet Allocation (LDA) merupakan sebuah metode statistika yang digunakan sebagai model untuk menganalisis suatu dokumen. $L D A$ berusaha untuk melihat dokumen dengan cara mundur untuk menemukan satu set topik yang mungkin telah dikoleksi. LDA merepresentasikan dokumen dengan berbagai topik yang dibuat berdasarkan probabilitas tertentu. Probabilitas topik, merepresentasikan kejelasan dari suatu dokumen [7]. Tahapan pemodelan topik pada penelitian ini akan menghasilkan topik-topik yang sesuai dengan tokoh politik, Basuki Tjahaja Purnama (Ahok), Joko Widodo, Anies Baswedan, Habib Rizieq, Sandiaga Uno. Inisialisasi nilai parameter LDA yaitu jumlah topik (didapat dari hasil klaster), nilai $\alpha$ atau Dirichlet (nilai $\alpha$ yaitu 50 per topik), nilai $\beta$ yaitu 0,1, jumlah iterasi 200. Berikut rumus LDA Persamaan 1.

$$
\mathrm{p}(\theta \mid \alpha)=\frac{\Gamma\left(\sum_{i=1}^{k} \alpha_{i}\right)}{\prod_{i=1}^{k} \Gamma\left(\alpha_{i}\right)} \prod_{i=1}^{k} \theta_{i}^{\alpha_{i}-1}
$$

Berikut hasil pemodelan topik $L D A$ dapat dilihat pada Gambar 4. 


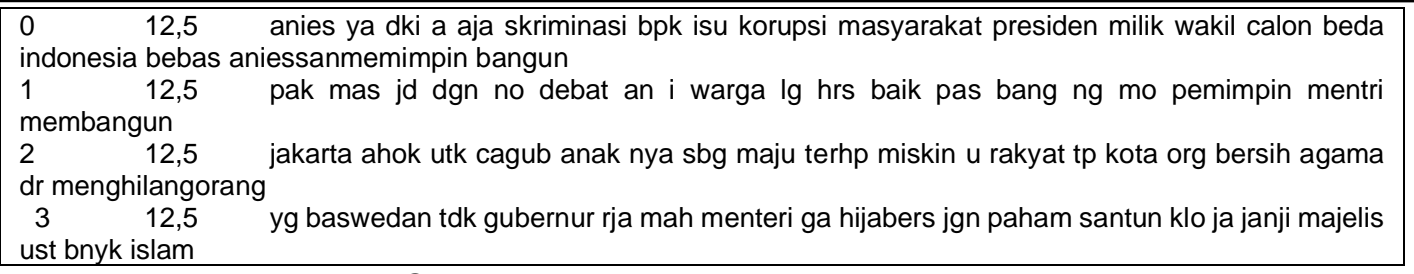

$$
\text { Gambar 4. Hasil LDA Berupa Topik }
$$

\subsubsection{Tahapan TF-IDF}

Tahapan keempat yang dilakukan ialah menghitung bobot pada setiap kata yang terdapat dalam masing-masing klaster dengan menggunakan perhitungan TF-IDF (Term Frequency Inverse Document Frequency). Metode TF-IDF (Term Frequncy Inverse Document Frequency) merupakan suatu cara untuk memberikan bobot hubungan suatu kata (term) terhadap dokumen. Metode ini menggabungkan dua konsep untuk perhitungan bobot yaitu, frekuensi kemunculan sebuah kata didalam sebuah dokumen tertentu dan inverse frekuensi dokumen yang mengandung kata tersebut [8]. Untuk melakukan pembobotan kata dengan TF-IDF, data hasil clustering digunakan sebagai acuan untuk menghitung pembobotan setiap kata pada masingmasing data klaster. Data dipecah menjadi masing-masing klaster, seperti pada data Ahok terdapat 4 klaster data utuh kemudian data dipecah menjadi tiap-tiap klaster sehingga data Ahok memiliki 4 data klister. Selanjutnya menghitung nilai TF setiap kata pada masing-masing data klister, serta menghitung nilai IDF setiap kata pada masing-masing data klaster. Dan menghitung nilai $T F-I D F$ setiap kata pada masing-masing data klaster, serta menghitung nilai rata-rata TF$I D F$ setiap tweet. Kemudian mencari tweet mana saja yang mengandung kata-kata terbanyak pada output LDA untuk dijadikan topik acuan. Berikut rumus tf-idf Persamaan 2.

$$
\mathrm{p}(\theta \mid \alpha)=W=t f x I D F
$$

Berikut merupakan hasil $T F, I D F$, rata-rata nilai $T F-I D F$ tiap tweet dapat dilihat pada Gambar 5, Gambar 6, dan Gambar 7.

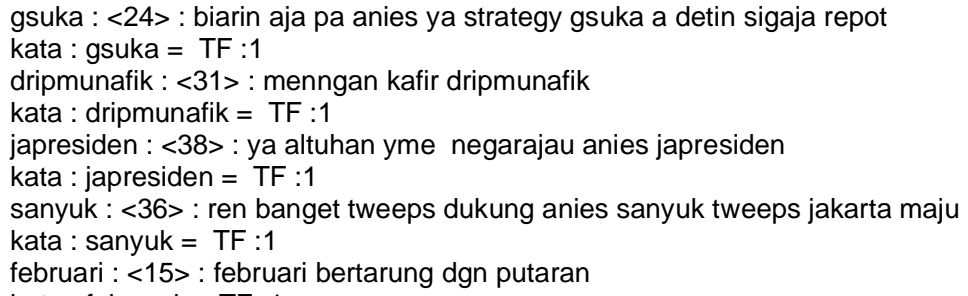

\section{Gambar 5. Hasil TF Kata}

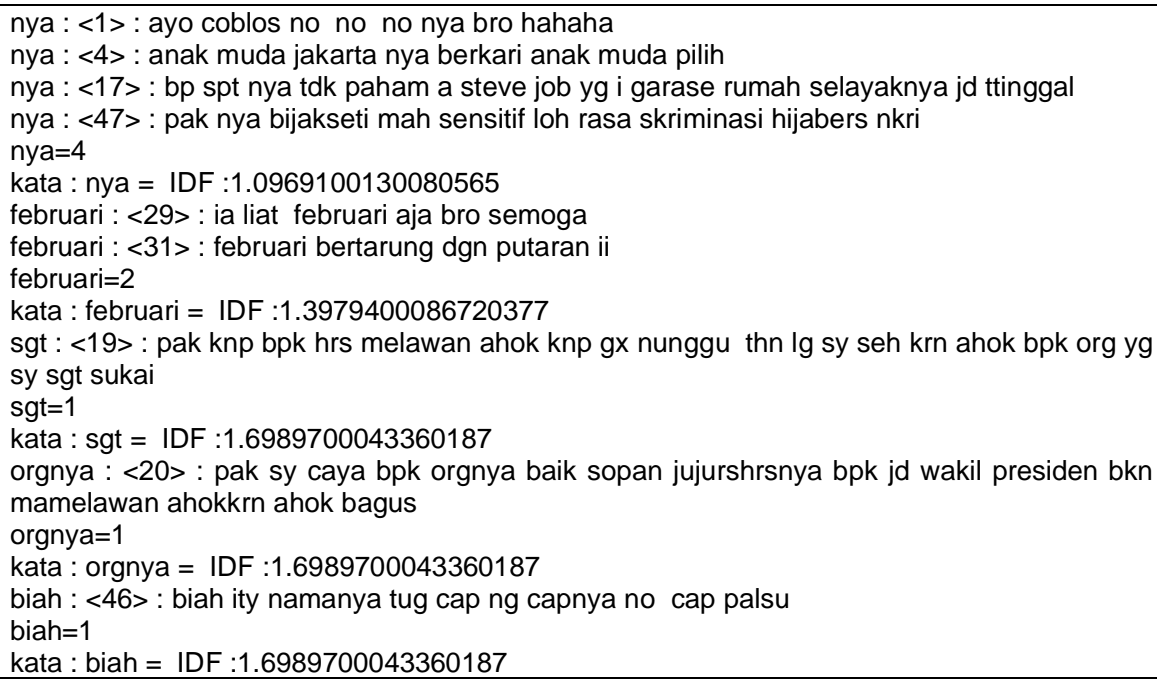

Gambar 6. Hasil IDF Kata 
pak knp bpk hrs melawan ahok knp gx nunggu thn lg sy seh krn ahok bpk org yg sy sgt sukai: 74.72939154903352

pak sy caya bpk orgnya baik sopan jujurshrsnya bpk jd wakil presiden bkn mamelawan ahokkrn ahok bagus: 56.25372603977551

ente tang jakarta ga jgn ng substansi beda ente yg ngga paham ama omongan org: 47.874440091787854

bp spt nya tdk paham a steve job yg i garase rumah selayaknya jd ttinggal: 46.402352032264055

gue gk interst jd mentri goblok kog malh cagub gayanya orator okopong penkn dah rusak skrg dki rusak: 45.47592205014354

mas jd cagub karna suruhan pepo sgkn mas gagal jd menteri: 44.24675539068267

Gambar 7. Hasil TF-IDF Tweet

\section{Hasil Penelitian dan Pembahasan}

Berikut merupakan hasil dari penelitian Deteksi Topik Tentang Tokoh Publik Politik Menggunakan Latent Dirichlet Allocation (LDA) dapat dijeaskan sebagai berikut :

\subsection{Preprocessing Data}

Pada tahap preprocessing data dilakukan dengan tujuan untuk menghilangkan kata-kata yang tidak penting yang terdapat dalam dokumen (Stopword Removal), untuk menghilangkan komponen dalam tweet yang tidak digunakan seperti @username, RT, \#Hastag, URL (Normalisasi Fitur), serta merubah huruf dalam tweet menjadi huruf kecil (Case Folding). Berikut hasil pada tahap preprocessing data ditunjukkan pada Gambar 7.

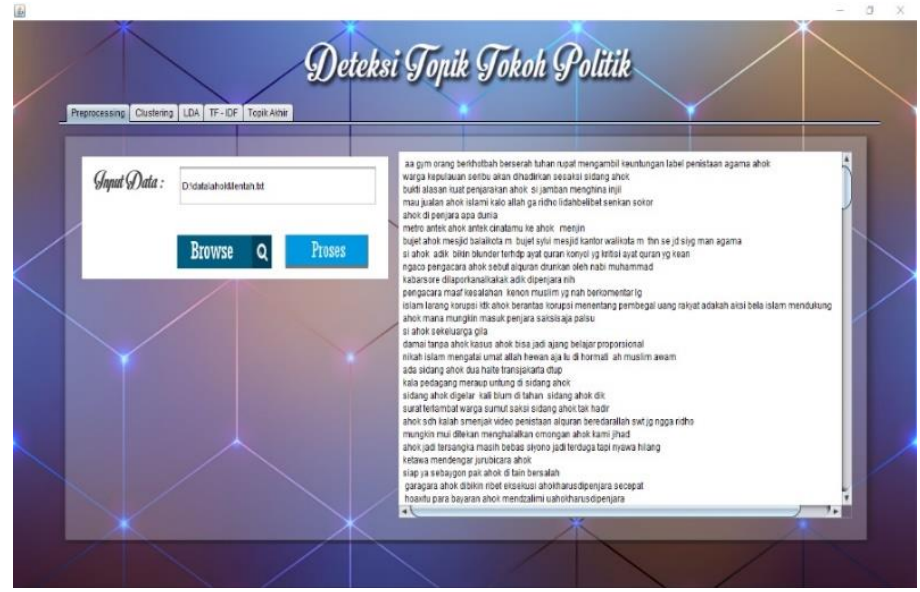

Gambar 8. Hasil Preprocessing Data

\subsection{Agglomerative Hierarchical Clustering}

Pada tahap klastering menggunakan Weka Library dimana hasil preprocessing disimpan dalam format .csv yang nantinya akan diubah dalam format .arff untuk bisa diolah menggunakan Weka Library. Selanjutnya menentukan parameter untuk proses klastering, Gambar 9 berikut contoh parameter klastering.

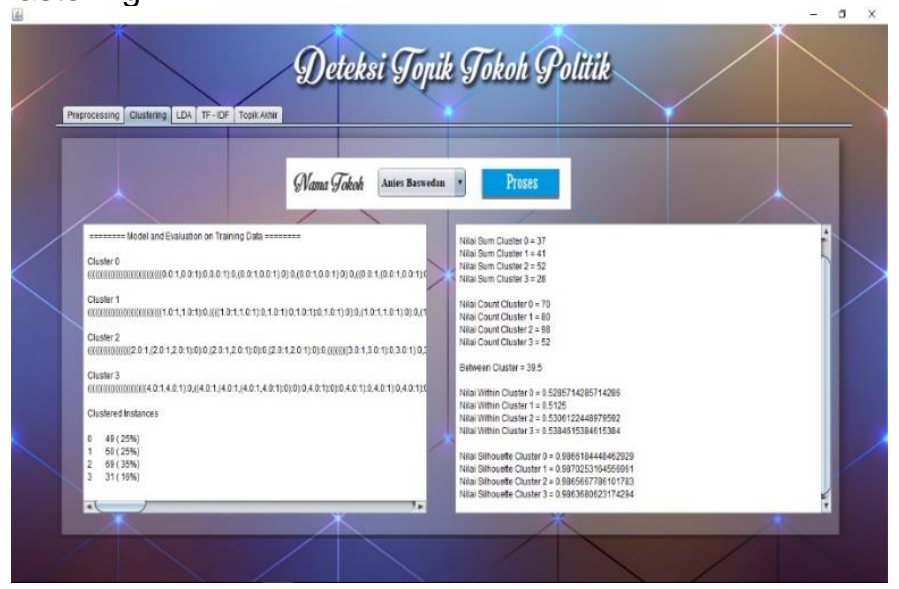

Gambar 9. Hasil Agglomerative Hierarchical Clustering

Deteksi Topik Tentang Tokoh Publik Politik... Faizun Nuril Hikmah, Setio Basuki, Yufis Azhar 


\subsection{Latent Dirichlet Allocation (LDA)}

Tahapan selanjutnya yaitu pemodelan topik menggunakan Latent Dirichlet Allocation (LDA) dimana pada pemodelan topik ini menggunakan hasil dari agglomerative clustering yang digunakan sebagai topik acuan. Pada tahap pemodelan topik $L D A$ data yang telah didapat dari hasil klaster dijadikan sebagai data input. Ketika data telah diinput, inisialisasi nilai parameter $L D A$ yaitu jumlah topik (didapat dari hasil klaster), nilai $\alpha$ atau Dirichlet (nilai a yaitu 50 per topik), nilai $\beta$ yaitu 0,1 , jumlah iterasi 200 . Berikut hasil pemodelan topik menggunakan $L D A$ ditunjukkan pada Gambar 10.

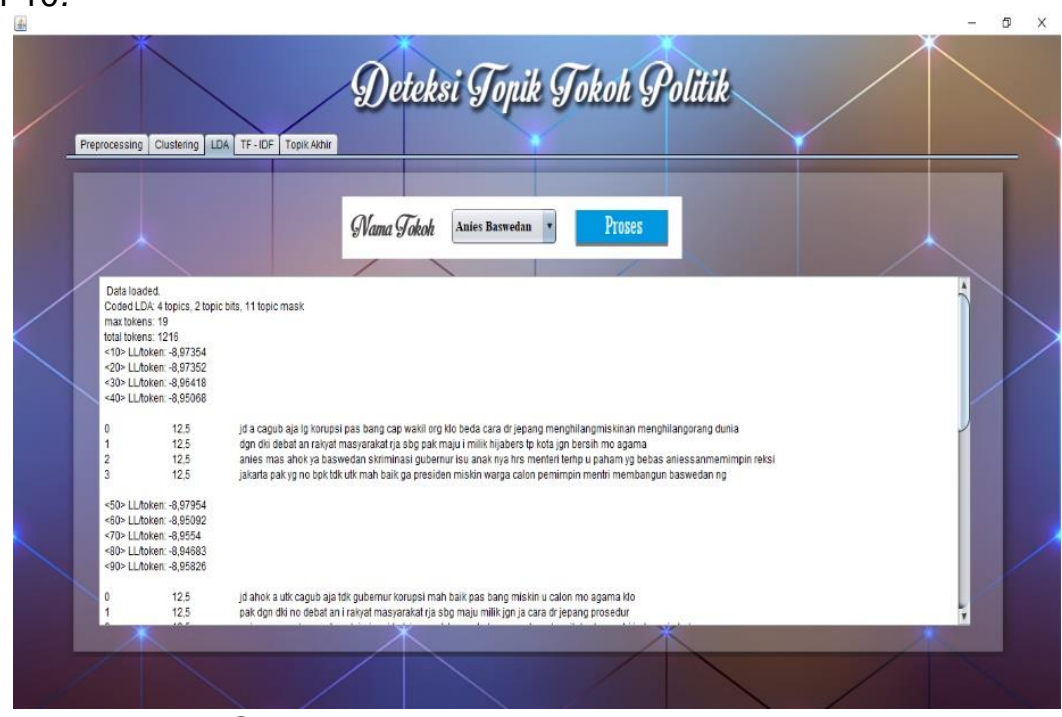

Gambar 10. Hasil Pemodelan Topik LDA

\subsection{TF-IDF}

Tahap selanjutnya yaitu TF-IDF, tahapan ini dilakukan dengan alasan pada tahap pemodelan topik $L D A$ kata pada topik-topik yang dihasilkan tidak mempunyai makna sehingga user akan sulit memahami apa arti dari topik-topik tersebut. Dengan menggunakan TF-IDF dapat mengetahui tweet mana saja yang memiliki kata-kata terbanyak pada hasil topik $L D A$, yang nantinya tweet dengan kata-kata terbanyak pada hasil topik $L D A$ yang akan digunakan sebagai topik acuan dan dengan tujuan agar user dapat memahami dan mengetahui makna dari topik. Berikut hasil TF-IDF ditunjukkan pada Gambar 11.

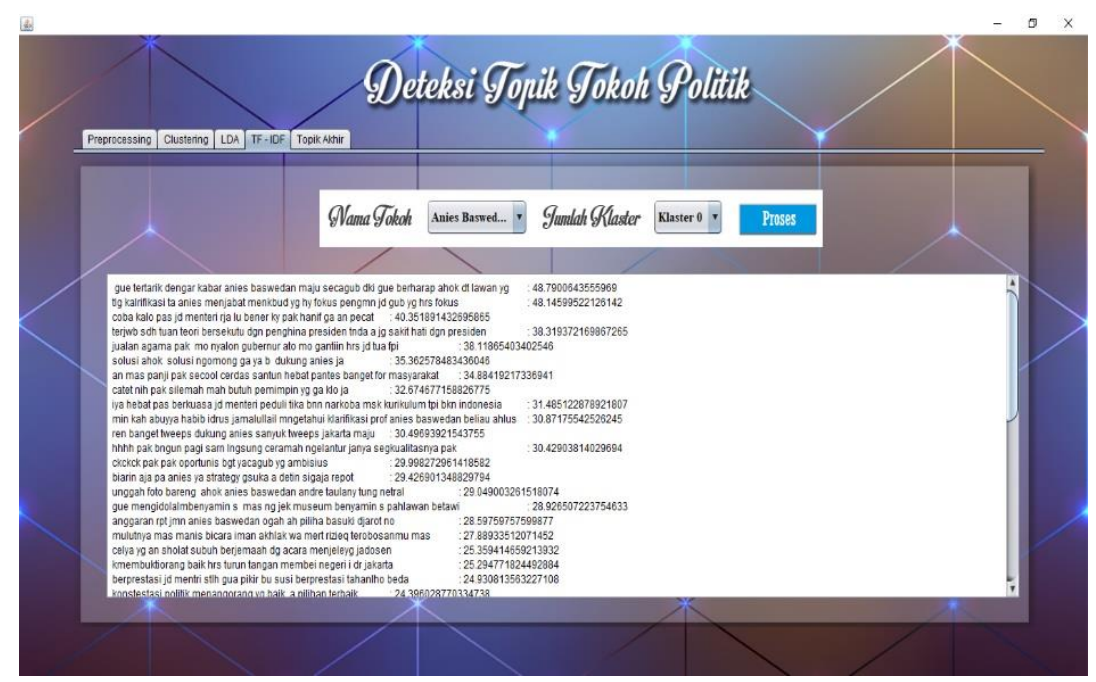

Gambar 11. Hasil TF-IDF

Dan berikut ini merupakan hasil tweet yang memiliki kata-kata terbanyak pada hasil topik LDA ditunjukkan pada Gambar 12.

REPOSITOR, Vol. 2, No. 4, April 2020: 415-426 


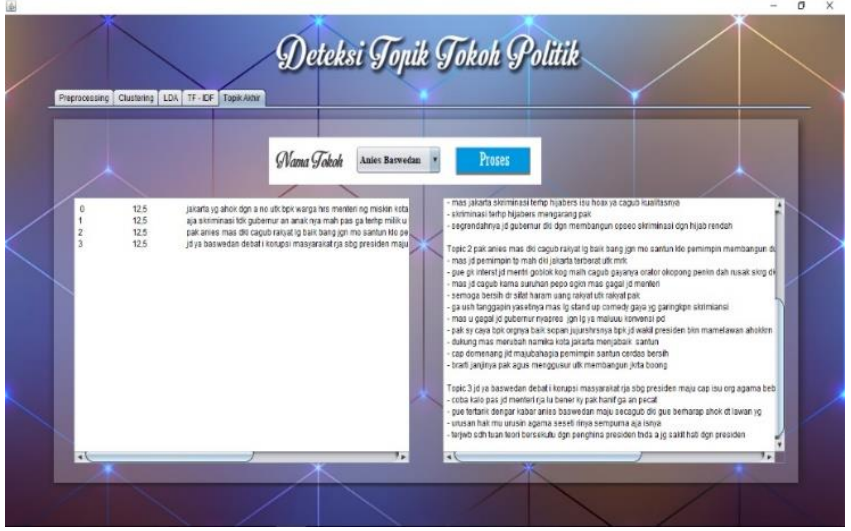

Gambar 12. Hasil Topik Akhir

\subsection{Silhouette Coefficient}

Metode yang digunakan dalam evaluasi hasil klastering yaitu Silhouette Coeffisient. Metode Silhouette Coeffisient berguna untuk menguji kualitas dari hasil klastering [9]. Pengujian hasil yang dilakukan pada tahapan klastering yaitu menggunakan metode pengujian Silhouette Index. Dengan menggunakan metode pengujian tersebut dapat diukur kevalidasian suatu data klaster tunggal ataupun keseluruhan klaster. Berikut hasil dari pengujian klastering menggunakan Silhouette Index seperti pada Tabel 3.

Tabel 3. Hasil Silhouette Coefficient Anies Baswedan

\begin{tabular}{cccc}
\hline $\begin{array}{c}\text { Cluster } \\
\text { ke- }\end{array}$ & Nilai Within (a) & Nilai Between $(\mathrm{b})$ & Hasil Silhouette \\
\hline 0 & 0.5285714285714286 & & 0.9866184448462929 \\
1 & 0.5125 & 39.5 & 0.9870253164556961 \\
2 & 0.5306122448979592 & & 0.9865667786101783 \\
3 & 0.5384615384615384 & & 0.9863680623174294 \\
\hline
\end{tabular}

Pada data Anies Baswedan didapatkan hasil Silhouette klaster-0 dengan nilai 0.9866184448462929 , klaster-1 dengan nilai 0.9870253164556961 , klaster-2 dengan nilai 0.9865667786101783 , klaster-3 dengan nilai 0.9863680623174294 . Hasil yang diperoleh pada data Anies Baswedan memiliki nilai diatas $0,7<S i<=1$ dengan struktur silhouette yang kuat, dengan kata lain data berada pada klaster yang tepat.

\subsection{Probability}

Pada $L D A$ sebuah topik digambarkan sebagai distribusi probability dari kata-kata. Artinya setiap topik memiliki probabilitas tertentu pada kata-kata yang ada dalam sebuah dokumen, topik yang berbeda akan memiliki nilai probabilitas yang berbeda pada kata yang sama. Misalnya pada sebuah topik yang menggambarkan tentang sains dan artikel teknologi yang lebih banyak menempatkan kemungkinan pada kata universitas daripada topik yang menggambarkan olahraga atau politik [10]. Untuk menganalisa topik yang telah dihasilkan pada tahapan LDA menggunakan probability. Analisa topik ini bertujuan untuk mengetahui probabilitas distribusi kata yang terdapat dalam topik di suatu dokumen. Dokumen yang digunakan dalam analisa topik ini berjumlah lima dokumen, diantaranya dokumen dari kelima tokoh politik yang digunakan dalam tugas akhir ini. Berikut hasil probability dapat dilihat pada Tabel 4.

Tabel 4. Hasil Probability Data Anies Baswedan

\begin{tabular}{|lllllll}
\hline \multicolumn{7}{|l}{ \#doc name topic proportion ... } \\
0 & bentuk & 0 & 0.2636363636363636 & 3 & \\
& 0.24545454545454545 & 2 & 0.24545454545454545 & 1 \\
& & 0.24545454545454545 & & & & \\
1 & gue & 2 & 0.2627118644067797 & 3 & 0.2457627118644068 \\
& 1 & 0.2457627118644068 & 0 & 0.2457627118644068 \\
2 & setahun & 3 & 0.2672413793103448 & 2 & 0.2672413793103448 \\
& 0 & 0.25 & 1 & 0.21551724137931033 & \\
\hline
\end{tabular}


Sebagai contoh pada data Anies Baswedan memiliki nilai probability sebagai berikut, pada dokumen 0 dengan kata bentuk pada topik 0 memiliki nilai probability 0.2636363636363636 , pada topik 1 memiliki nilai probability 0.24545454545454545 , pada topik 2 memiliki nilai probability 0.24545454545454545 , pada topik 3 memiliki nilai probability 0.24545454545454545 . Dapat dilihat nilai probability terbesar didapatkan dengan kata bentuk dalam topik 0 itulah yang sesuai sebagai topik 0 . Pada dokumen 1 dengan kata gue pada topik 0 memiliki nilai probability 0.2457627118644068 , pada topik 1 memiliki nilai probability 0.2457627118644068 , pada topik 2 memiliki nilai probability 0.2627118644067797 , pada topik 3 memiliki nilai probability 0.2457627118644068 . Dapat dilihat nilai probability terbesar didapatkan dengan kata gue dalam topik 2 itulah yang sesuai sebagai topik 2. Pada dokumen 2 dengan kata setahun pada topik 0 memiliki nilai probability 0.25 , pada topik 1 memiliki nilai probability 0.21551724137931033 , pada topik 2 memiliki nilai probability 0.2672413793103448 , pada topik 3 memiliki nilai probability 0.2672413793103448 . Dapat dilihat nilai probability terbesar didapatkan dengan kata gue dalam topik 2 itulah yang sesuai sebagai topik 2 . Jika nilai probability pada masing-masing topik terdapat nilai probability yang paling besar dari nilai probability topik yang lainnya, maka nilai probability terbesar itulah yang sesuai dengan topik tersebut seperti penjelasan diatas.

\section{Kesimpulan}

Pada penelitian ini hasil evaluasi klastering sudah berada di struktur kuat yaitu pada rentang antara $0,7<S i<=1$. Hal tersebut telah membuktikan bahwa anggota-anggota dalam masing-masing klaser sudah berada dalam klaster yang tepat. Hasil pemodelan topik pada LDA yang memiliki nilai probability yang lebih tinggi dari yang lainnya menunjukkan bahwa kata dalam sebuah dokumen tersebut merupakan kata yang tepat pada topik. Dengan hasil evaluasi pengujian silhouette coefficient pada tahap klaster, menunjukkan bahwa algoritma agglomerative hierarchical clustering merupakan algoritma yang sesuai dan bagus untuk digunakan pada tugas akhir ini. Pada tahapan pemodelan topik LDA memiliki output topik-topik mengenai tokoh politik. Topik-topik tersebut berisi kata-kata dan tidak ada makna, sehingga user akan sulit memahami topik-topik tersebut. Oleh karena itu, pada tugas akhir ini menggunakan metode TF-IDF untuk mengetahui nilai rata-rata setiap tweet dan mengetahui tweet mana saja yang mengandung katakata terbanyak dalam output $L D A$. Dengan menggunakan metode $T F-I D F$, user akan lebih mudah mengetahui makna dari output yang dihasilkan pada tahapan $L D A$.

\section{Daftar Notasi}

Berikut daftar notasi yang terdapat pada jurnal sebagai berikut :

D : dokumen

DF : dokumen frekuensi

W : :tf-idf

$\theta \quad$ : distribusi topik dalam dokumen

a $\quad$ : parameter Dirichlet sebelumnya pada distribusi topik per dokumen

k : jumlah topik

\section{Referensi}

[1] Jain AP. Sentiments Analysis Of Twitter Data Using Data Mining. 2015;807-10.

[2] Alashri S, Ravi R, Smith KL, Desouza KC. An Analysis of Sentiments on Facebook during the 2016 U.S. Presidential Election. 2016;795-802.

[3] Tembhurnikar SD, Patil NN. Topic Detection using BNgram Method and Sentiment Analysis on Twitter Dataset. 2015;

[4] Alfina T, Santosa B, Barakbah R. Analisa Perbandingan Metode Hierarchical Clustering, Kmeans dan Gabungan Keduanya dalam Cluster Data ( Studi kasus : Problem Kerja Praktek Jurusan Teknik Industri ITS ). 2012;1.

[5] Februariyanti H. Klastering Dokumen Menggunakan Hierarchical Agglomerative Clustering. 2009;

[6] PTIIK-UB. Pengenalan Pola Hierarchical Clustering. 2014;

[7] Agustina A. Analisis dan Visualisasi Suara Pelanggan Pada Pusat Layanan Pelanggan Dengan Pemodelan Topik Menggunakan Latent Dirichlet Allocation (LDA) Studi Kasus: PT. PETROKIMIA Gresik. 2017;

[8] Putung KD, Lumenta A, Jacobus A, Informatika T, Sam U, Manado R. Penerapan Sistem Temu Kembali Informasi Pada Kumpulan Dokumen Skripsl. 2016;8(1).

REPOSITOR, Vol. 2, No. 4, April 2020: 415-426 
[9] Kurniawan AA. Implementasi Algoritma Agglomerative Hierarchical Clustering Untuk Mengelompokkan Capaian Belajar Siswa SD. 2017;

[10] Hansen J V. Inside Latent Dirichlet Allocation: An Empirical Exploration Inside Latent Dirichlet Allocation : An Empirical Exploration. 
REPOSITOR, Vol. 2, No. 4, April 2020: 415-426 